\title{
Cytotoxicity of Bacillus piliformis
}

\author{
L. K. RILEY, C. J. CAFFREY, V. S. MUSILLE and J. K. MEYER
}

Department of Veterinary Pathology, University of Missouri, Columbia, Missouri 65211, USA

\begin{abstract}
Summary. Seven isolates of $B$. piliformis, the agent of Tyzzer's disease, obtained from various host species, were examined for cytotoxic activity by incubating culture filtrates on BRL 3A rat-hepatocyte and 3T3 mouse-fibroblast cell lines. One isolate exhibited cytopathic effects on BRL 3A cells, but not on 3T3 cells. Three other isolates were strongly cytotoxic for 3T3 cells but only slightly so for BRL 3A cells. The remaining three isolates showed no cytotoxicity for either cell line. The cytotoxic products were $>100 \mathrm{kDa}$ in mol. wt, thermolabile, and partly destroyed by trypsin treatment. The data show that some $B$. piliformis isolates produce cytotoxic proteins, which may contribute to the pathogenesis of Tyzzer's disease.
\end{abstract}

\section{Introduction}

Bacillus piliformis is a long (10 $40 \mu \mathrm{m})$, rod-shaped, gram-negative, spore-forming, motile, obligately intracellular bacterium, originally described and named by Tyzzer. ${ }^{1}$ It causes an often fatal enterohepatic syndrome in a wide range of domestic, laboratory, and wild animal species, ${ }^{2-4}$ in primates, ${ }^{5}$ and possibly in man. ${ }^{6}$ Infection may produce a watery to pasty diarrhoea ${ }^{2,3}$ and oedema, haemorrhage, inflammation, and focal ulceration in intestinal and hepatic tissue. The intestinal lamina propria is distended and contains a polymorphonuclear cell infiltrate. $B$. piliformis organisms are visible within the absorptive and crypt epithelial cells of the terminal ileum and colon.

Diarrhoea with histopathological changes such as those described is characteristic of cytotoxin-producing bacteria, such as Shigella spp., ${ }^{7}$ Escherichia coli strains that produce Shiga-like toxins, ${ }^{8}$ and Campylobacter jejuni. ${ }^{9,10}$ The present study was undertaken to examine the possibility that $B$. piliformis may produce cytotoxins.

\section{Materials and methods}

\section{Preparation of culture filtrates}

Seven isolates (B, G, H, GP, M, E, R1) of $B$. piliformis obtained from naturally infected animals in diverse geographical locations ${ }^{11}$ were used. Isolate $\mathbf{B}$ was grown on 3T3 mouse fibroblasts (MA Bioproducts, Walkersville, MD, USA); all other isolates were grown on buffalo rat liver cells (BRL 3A; ATCC CRL 1442) as previously described, ${ }^{11}$ unless otherwise

Received 18 June 1991; accepted 29 Aug. 1991. noted. Briefly, mammalian cell monolayers were grown at $37^{\circ} \mathrm{C}$ in Dulbecco Modified Eagle Medium (DMEM) supplemented with Serum Plus (Hazelton, Lenexa, KS, USA) $10 \%$ and $2 \mathrm{~mm}$ L-glutamine (Sigma Chemical Co., St Louis, MO, USA) until 70-80\% confluent. The monolayers were inoculated with $B$. piliformis and incubated at $37^{\circ} \mathrm{C}$ until the bacterial concentrations reached $10^{5}-10^{6} / \mathrm{ml}$. Culture medium was harvested and filtered through a $0.22-\mu \mathrm{m}$ membrane filter. Except where specifically indicated, filtrates were either used immediately or after storage at $4^{\circ} \mathrm{C}$. For trypsin sensitivity experiments, bacterial cultures were grown as described above, except that the Serum Plus was decreased to $1 \%$.

As controls, culture filtrates and mammalian cell extracts were prepared from analogous monolayers not infected with $B$. piliformis. The extracts were prepared from monolayers that were harvested by scraping and disrupted ultrasonically at $105 \mathrm{~W}$ (Branson Sonic Power Company, Danbury, CT, USA) on ice for three 30-s bursts.

\section{Cytotoxin assays}

A modification of the spectrophotometric method of Gentry and Dalrymple ${ }^{12}$ was used to quantitate cytotoxic activity in culture filtrates. Mammalian cell lines used as target cells in cytotoxicity assays included 3T3 mouse fibroblast, BRL 3A rat liver, monkey kidney (Vero; ATCC CCL 81), human embryonic intestine (Henle 407; ATCC CCL 6), and human cervical epithelioid carcinoma (HeLa; ATCC CCL2). Plastic plates containing 96 wells (Becton Dickinson Labware, Lincoln Park, NJ, USA) were seeded with target cells $(16000 /$ well) and incubated overnight at $37^{\circ} \mathrm{C}$; the growth medium $(0.2 \mathrm{ml} /$ well $)$ was then removed. To each well was next added $0.2 \mathrm{ml}$ of culture filtrate diluted 1 in 2 with fresh medium, unless 
otherwise stated; for control purposes fresh medium $(0.2 \mathrm{ml})$ was added to each well. After incubation for $48 \mathrm{~h}$ at $37^{\circ} \mathrm{C}$, plates were washed with phosphatebuffered saline, $\mathrm{pH} 7.2$ (PBS), to remove detached cells. Remaining cells were fixed in formalin and stained with crystal violet. Excess stain was removed by rinsing with water, and the dye was eluted with ethanol $50 \%$. The percentage of surviving cells was quantitated by comparing the absorbance of the eluted dye at $570 \mathrm{~nm}$ with that of the appropriate control. All experiments were performed on 3-6 culture-filtrate samples collected and assayed on separate occasions, each sample being tested in triplicate. Percentage of cytotoxicity was calculated as $100-\left[\left(\mathrm{A}_{570}\right.\right.$ of experimental sample $/ A_{570}$ of control samples) $\left.\times 100\right]$.

\section{Characterisation of cytotoxic activity}

To assess the effect of storage on cytotoxicity, samples of culture filtrates were stored at 0 and $-20^{\circ} \mathrm{C}$. At intervals, samples were removed and tested for cytotoxic activity on HeLa cells. The cytotoxicity values were compared with those determined immediately after harvest of culture filtrate.

To define the heat stability of cytotoxin, culture filtrates were heated in a water bath at 50,60 or $80^{\circ} \mathrm{C}$ for $30 \mathrm{~min}$. Cytotoxicity for HeLa cells was compared with that of unheated culture filtrate.

Mol.-wt ranges of cytotoxic factors were determined by ultrafiltration of culture filtrates on Amicon membranes (Amicon Corp., Danvers, MA, USA). Membranes were presoaked for $30 \mathrm{~min}$ in $\mathrm{NaCl} 5 \%$ and then rinsed for $1 \mathrm{~h}$ in three changes in deionised water before use. Fractions of defined size ranges $(<10$, $10-30,30-100$ and $>100 \mathrm{kDa}$ ) were prepared from each culture filtrate. The cytotoxicity of each fraction, as compared with that of unfractionated culture filtrate, was then determined on HeLa cells.

To determine whether cytotoxins were composed of protein, culture filtrates were treated with trypsin $(2 \mathrm{mg} / \mathrm{ml})$ (Sigma) as previously described ${ }^{13}$ After incubation for $30 \mathrm{~min}$ at $37^{\circ} \mathrm{C}$, the trypsin was inactivated by the addition of soy bean trypsin inhibitor at a ratio of $2.7 \mathrm{mg}$ of inhibitor to $1.0 \mathrm{mg}$ of trypsin, and the percent cytotoxicity was determined. Controls consisted of untreated culture filtrates and culture filtrates treated with trypsin which had been pre-incubated with trypsin inhibitor.

\section{Statistical analyses}

Statistical analyses were performed by Student's $t$ test.

\section{Results}

\section{Cytotoxicity of culture filtrates}

To investigate cytotoxicity, filtrates from cultures of mammalian cells infected with various $B$. piliformis
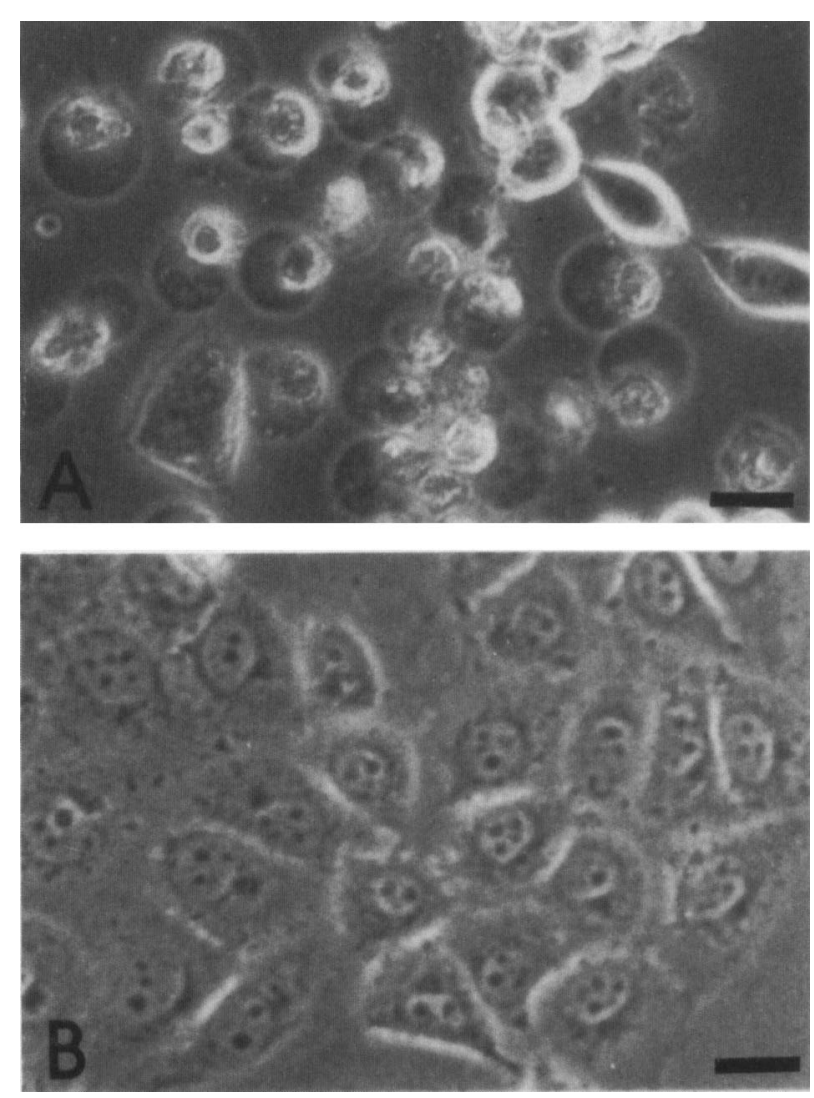

Fig. 1. Effect of culture filtrates on mammalian cell monolayers BRL 3A cells incubated with filtrate from $B$. piliformis-infected (A) and uninfected (B) cell cultures. Bar $=20 \mu \mathrm{m}$.

isolates were tested initially on BRL 3A rat-hepatocyte and 3T3 mouse-fibroblast cell lines. After incubation of filtrates from isolate B with BRL $3 \mathrm{~A}$ cells at $37^{\circ} \mathrm{C}$ for $48 \mathrm{~h}$, phase-contrast light microscopy revealed rounding and detachment of the cells; identical monolayers incubated with filtrates from uninfected mammalian cell cultures remained attached and almost confluent (fig. 1). Similar cytopathic effects were seen with filtrates from isolates $\mathrm{G}, \mathrm{H}$ and $\mathrm{GP}$ on $3 \mathrm{~T} 3$ cells.

Cytotoxic activity was assayed in culture filtrates prepared from seven $B$. piliformis isolates on BRL 3A and $3 \mathrm{~T} 3$ cells (table I). Filtrate from isolate $B$ was cytotoxic for BRL 3A cells but not for 3T3 cells. In contrast, filtrates from isolates G, H and GP showed

Table I. Cytotoxicity of $B$. piliformis culture filtrates on 3T3 and BRL 3A mammalian cells

\begin{tabular}{|c|c|c|c|}
\hline \multirow{2}{*}{ Isolate } & \multirow{2}{*}{$\begin{array}{l}\text { Number } \\
\text { of samples } \\
\text { tested }\end{array}$} & \multicolumn{2}{|c|}{$\begin{array}{c}\text { Mean (SEM) percentage cytotoxicity } \\
\text { on mammalian cells }\end{array}$} \\
\hline & & $3 \mathrm{~T} 3$ & BRL 3A \\
\hline B & 6 & $0.2(0.6)$ & $92 \cdot 8(1.0)$ \\
\hline G & 3 & $62.6(2.9)$ & $9.3(2.9)$ \\
\hline $\mathrm{H}$ & 3 & $56.0(3 \cdot 2)$ & $1 \cdot 5(1 \cdot 2)$ \\
\hline GP & 3 & $67.0(3.3)$ & $18 \cdot 3(2 \cdot 1)$ \\
\hline $\mathbf{M}$ & 3 & $0 \cdot 0(2 \cdot 1)$ & $0.0(1.9)$ \\
\hline E & 3 & $0.0(3.2)$ & $0.0(2.3)$ \\
\hline Rl & 3 & $0.0(2.2)$ & $0.0(3.6)$ \\
\hline
\end{tabular}


Table II. Cytotoxicity of $B$. piliformis filtrates on various mammalian cell lines

\begin{tabular}{lc|ccc}
\hline & \multicolumn{3}{|c}{$\begin{array}{c}\text { Number } \\
\text { of samples } \\
\text { tested }\end{array}$} & \multicolumn{3}{|c}{$\begin{array}{c}\text { Mean (SEM) percentage cytotoxicity } \\
\text { on mammalian cells }\end{array}$} \\
\cline { 3 - 5 } & & Vero & Henle & HeLa \\
\hline B & 6 & $86.5(1.5)$ & $31.3(2.6)$ & $87.7(1.8)$ \\
G & 3 & $96.3(2.3)$ & $90.0(1.3)$ & $89.3(0.7)$ \\
H & 3 & $46.0(2.8)$ & $72.5(1.6)$ & $77.0(1.0)$ \\
GP & 3 & $89.3(2.6)$ & $88.8(1.4)$ & $90.0(1.3)$ \\
\hline
\end{tabular}

much greater cytotoxicity for $3 \mathrm{~T} 3$ cells than for BRL $3 \mathrm{~A}$ cells. No significant difference in cytotoxicity for 3T3 cells was noted between filtrates from isolates $G$, $H$ and GP. Culture filtrates from isolates $M, E$ and $R 1$ showed no cytotoxic activity against either cell line. Similar results were obtained when isolates $\mathrm{G}, \mathrm{H}, \mathrm{GP}$, $M, E$ and $R 1$ were grown in $3 \mathrm{~T} 3$ cells rather than BRL $3 \mathrm{~A}$ cells, although the cytotoxic activities of isolates $\mathrm{G}$, $\mathrm{H}$ and GP were reduced (data not shown). Analogous experiments in which isolate $\mathrm{B}$ was grown on BRL $3 \mathrm{~A}$ cells were not performed as the organism could not be propagated in this cell line despite repeated attempts; the cells in BRL 3A monolayers inoculated with isolate $B$ invariably became rounded and detached, preventing bacterial growth. Because no cytotoxicity was observed with isolates $\mathrm{M}, \mathrm{E}$ and $\mathrm{R} 1$, the remainder of the studies were performed only on isolates $\mathrm{B}, \mathrm{G}, \mathrm{H}$ and GP.

To confirm that degradative products from lysed mammalian cells in which bacteria were grown were not responsible for the observed cytopathic effects, extracts of uninfected 3T3 and BRL 3A cells were prepared and applied to BRL 3A and 3T3 target cell monolayers, respectively. Monolayers were examined for cytopathic effects after incubation at $37^{\circ} \mathrm{C}$ for 24 , 48 and $72 \mathrm{~h}$. The results were negative, indicating that mammalian cell components were not cytotoxic.

To prove that cytotoxicity was not due to the depletion of medium nutrients during the incubation of cytotoxicity assays, culture filtrates of isolate B were diluted 1 in 50 in fresh medium and the toxicity was assayed. The diluted samples showed $93 \%$ of the cytotoxity of undiluted culture filtrates. Similar effects were seen with culture filtrates from other cytotoxinogenic isolates. These data, coupled with the lack of cytotoxicity in assays of filtrates from isolates $\mathrm{M}, \mathrm{E}$ and $R 1$, indicated that nutrient depletion was not responsible for the cytopathic effects.

To assess whether other cell lines previously documented as sensitive to cytotoxins of invasive bacteria were sensitive to $B$. piliformis cytotoxin, culture filtrates from the four cytotoxinogenic isolates shown were incubated with Vero, Henle 407 and HeLa cells (table II). All four had significantly increased cytotoxic activity against these cell lines as compared with filtrates from uninfected control cultures $(p \leqslant 0.01)$. Control wells in which extracts of uninfected BRL 3A

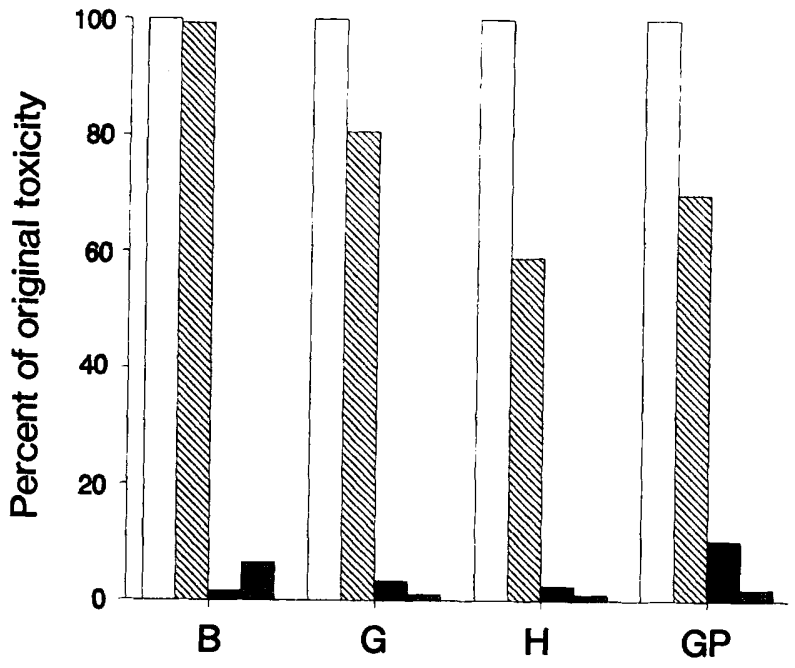

Fig. 2. Effect of heat treatment $\left(\triangle, 50^{\circ} \mathrm{C} ; \square, 60^{\circ} \mathrm{C}\right.$; 圈, $\left.80^{\circ} \mathrm{C}\right)$ on cytotoxic activity of isolates $\mathrm{B}, \mathrm{G}, \mathrm{H}$ and $\mathrm{GP}$. Values represent the mean percentage of cytotoxicity of the appropriate untreated control (口).

and $3 \mathrm{~T} 3$ cells were applied to Vero, Henle 407 and HeLa cells exhibited no cytotoxicity, indicating that toxicity on these cell lines, like that described in BRL $3 \mathrm{~A}$ and $3 \mathrm{~T} 3$ cells, was not due to a mammalian cell product.

\section{Characterisation of cytotoxic products}

To facilitate characterisation and comparison of cytotoxins produced by the various isolates of $B$. piliformis, all subsequent assays were performed on HeLa cell monolayers.

The stability of cytotoxin was evaluated at various temperatures. Filtrates from infected cultures stored at $4^{\circ} \mathrm{C}$ showed $<10 \%$ loss of activity in 60 days. Samples stored at $-20^{\circ} \mathrm{C}$ for 2 weeks had lost $>60 \%$ of cytotoxic activity. Thermal stability of culture filtrates was determined by heating the samples at 50 , 60 or $80^{\circ} \mathrm{C}$ for $30 \mathrm{~min}$. The cytotoxins from all four isolates were heat-labile, retaining $<10 \%$ of the original cytotoxicity after treatment at $60^{\circ} \mathrm{C}$ for $30 \mathrm{~min}$ (fig. 2). Fractions of culture filtrates obtained by means of molecular sieving membranes were examined. Those of $<100 \mathrm{kDa}$ were only slightly, if at all, cytotoxic. Those of $>100 \mathrm{kDa}$ destroyed mammalian cell monolayers (table III).

To assess the effect of trypsin on cytotoxicity, the amount of protein in culture filtrates was decreased by

Table III. Cytotoxicity of culture filtrates fractionated by ultrafiltration

\begin{tabular}{l|cc}
\hline \multirow{2}{*}{ Isolate } & $\begin{array}{c}\text { Mean (SEM) percentage cytotoxicity of } \\
\text { culture filtrate fractions on HeLa cells }\end{array}$ \\
\cline { 2 - 3 } & $<100 \mathrm{kDa}$ & $>100 \mathrm{kDa}$ \\
\hline B & $0.0(0 \cdot 0)$ & $98.0(2.8)$ \\
G & $11.5(2 \cdot 1)$ & $89.2(3.1)$ \\
H & $3.8(2.0)$ & $100.0(4.5)$ \\
GP & $0.0(0.0)$ & $89.8(3.0)$ \\
\hline
\end{tabular}


growing the organisms in medium containing serum $1 \%$ supplement rather than $10 \%$ as routinely used in culture of mammalian cells. This did not adversely affect cytotoxinogenesis (data not shown). Treatment of culture filtrates with trypsin $2 \mathrm{mg} / \mathrm{ml}$ at $37^{\circ} \mathrm{C}$ for $30 \mathrm{~min}$ destroyed $70-80 \%$ of the cytotoxin from isolates $\mathrm{B}, \mathrm{G}, \mathrm{H}$ and GP. This effect was specifically blocked by pre-incubation of the trypsin with soy bean trypsin inhibitor.

\section{Discussion}

This study showed that four of seven B. piliformis isolates produced substances cytotoxic to $3 \mathrm{~T} 3$ mouse fibroblasts and BRL $3 \mathrm{~A}$ rat hepatocytes. Inability to propagate isolate $B$ on BRL 3A may have been due to cytotoxin production; the rat hepatocytes became rounded and detached after inoculation, preventing bacterial growth. Possibly the lower cytotoxicity observed when isolates $\mathrm{G}, \mathrm{H}$ and GP were grown on $3 T 3$ rather than BRL 3A cells may reflect uptake of cytotoxin by the cell monolayers during propagation. Preliminary characterisation of the cytotoxin revealed thermal lability and sensitivity to trypsin treatment, suggesting that the active components were protein in nature.

Earlier investigators recognised heterogeneity in $B$. piliformis, with variable degrees of immunological cross-reactivity ${ }^{14,15}$ and differences in protein and antigenic profiles. ${ }^{11}$ These findings have prompted speculation that $B$. piliformis has a number of biovars. In this study, cytotoxins produced by different $B$. piliformis isolates varied in mammalian cell specificity. The isolates could be classified as follows: (1) isolate B, cytotoxic for BRL 3A cells; (2) those cytotoxic for 3T3 cells but with little if any cytotoxicity for BRL $3 \mathrm{~A}$ cells (isolates G, H and GP); and (3) those lacking cytotoxicity for both cells lines (isolates $\mathrm{E}, \mathrm{M}$ and $\mathrm{R} 1$ ). Isolates $\mathrm{G}, \mathrm{H}$ and $\mathrm{GP}$, which each produced cytotoxin active against $3 \mathrm{~T} 3$ cells, are antigenically the most similar of the seven isolates examined. ${ }^{11}$ Further information on cytotoxins may facilitate taxonomic classification and delineation of biovars in $B$. piliformis.

Culture filtrates from B. piliformis were toxic for various mammalian cell types including fibroblasts, liver, kidney and epithelial cells. This may indicate that the toxic factor utilises a non-specific cytotoxic mechanism or that it binds to membrane receptors found on numerous cell types.

Further study of cytotoxicity of B. piliformis may yield information on the pathogenesis of Tyzzer's disease. Two forms of Tyzzer's disease are recognised in animals - an acute clinical form, mainly affecting weanling animals or those with reduced resistance, and a subclinical form, occurring mainly in adult animals and liable to develop into acute clinical diseases as a result of adverse environmental circumstances. It seems possible that non-cytotoxinogenic $B$. piliformis isolates are of reduced virulence and therefore more likely to cause subclinical disease.

The role, if any, of cytotoxins in the mucosal necrosis and diarrhoea associated with Tyzzer's disease remains to be elucidated. Possibly they assist the organism in invading enterocytes or hepatocytes, or cause lysis of the host cells after intracellular multiplication has occurred.

We thank $\mathrm{H}$. Wilson for photographic work, and R. Hook and M. Riley for a critical review of the manuscript. This work was supported by Public Health Service grant RR-04568 from the National Institutes of Health.

\section{References}

1. Tyzzer EE. A fatal disease of the Japanese waltzing mouse caused by a spore-bearing bacillus (Bacillus piliformis, $\mathrm{N}$. Sp.). J Med Res 1917; 37: 307-338.

2. Fujiwara K. Tyzzer's disease. Jpn J Exp Med 1978; 48: 467-480.

3. Ganaway JR, Allen AM, Moore TD. Tyzzer's disease. Am J Pathol 1971; 64: 717-732.

4. Webb DM, Harrington DD, Boehm PN. Bacillus piliformis infection (Tyzzer's disease) in a calf. $J$ Am Vet Med Assoc 1987; 191: 431-434.

5. Niven JSF. Tyzzer's disease in laboratory animals. $Z$ Versuchstierkd $1968 ; 10$ : 168-174.

6. Fries A. Antibodies to Bacillus piliformis (Tyzzer's disease) in sera from man and other species. In: Spiegel A, Erichsen S, Solleveld HA (eds) Animal quality and models in biomedical research: 7th ICLAS Symposium, Utrecht. Stuttgart, Gustav Fischer Verlag. 1980: 249-252.

7. Rout WR, Formal SB, Giannella RA, Dammin GJ. The pathophysiology of Shigella diarrhea in the rhesus monkey; intestinal transport, morphological and bacteriological studies. Gastroenterology 1975; 68: 270-278.

8. O'Brien AD, Nataro JP. New concepts in the pathogenesis of enteropathogenic Escherichia coli diarrhea. In: Leive L

(ed) Microbiology 1985. Washington, DC, American Society for Microbiology. 1987: 78 .

9. Guerrant RL, Wanke CA, Pennie RA, Barrett LJ, Lima AAM, O'Brien AD. Production of a unique cytotoxin by Campylobacter jejuni. Infect Immun 1987; 55: 2526-2530.

10. Klipstein F, Engert RF, Short H, Schenk EA. Pathogenic properties of Campylobacter jejuni: assay and correlation with clinical manifestations. Infect Immun 1985; 50 : 43-49.

11. Riley LK, Besch-Williford C, Waggie KS. Protein and antigenic heterogeneity among isolates of Bacillus piliformis. Infect Immun 1990; 58: 1010-1016.

12. Gentry MK, Dalrymple JM. Quantitative microtiter cytotoxicity assay for Shigella toxin. J Clin Microbiol 1980; 12 361-366.

13. Ashkenazi S, Cleary TG, Murray BE, Wanger A, Pickering LK Quantitative analysis and partial characterization of cytotoxin production by Salmonella strains. Infect Immun 1988; 56: 3089-3094.

14. Fries AS. Studies on Tyzzer's disease: comparison between Bacillus piliformis strains from mouse, rat and rabbit. Lab Anim 1980; 14: 61-63.

15. Fujiwara K, Yamada A, Ogawa H, Oshima Y. Comparative studies on the Tyzzer's organisms from rats and mice. Jpn J Exp Med 1971; 41 : 125-133. 